\title{
Development and Security in the Nigerian Democratic Dispensation \\ DOI: 10.36108/NJSA/2102/01(0190)
}

\author{
Adedayo Adedoyin \\ School of General Studies \\ Michael Okpara University of Agriculture \\ Umudike, Abia State, Nigeria
}

Vol. 10 Issue 1, 2012

\begin{abstract}
For more than five decades, Nigeria has witnessed series of efforts toward development which have been largely unsuccessful. With the aid of secondary data from various sources, this paper discusses the issue of Nigeria's development aspiration in relationship to its security problems. The paper contends that the absence of good governance and insecurity have engendered elements of unaccountability, political division, disunity, violence, deprivation of infrastructural facilities, unemployment, etc. which constituted obstacles to the country's development aspirations. Good socio-political and economic systems are identified as the key objectives to Nigeria's development in the 21st century. In this dispensation, Nigeria has failed to fashion out its own development brands, while a successful development can only be achieved through a home-grown strategy and not necessarily through imported ideas or theories. The elements of good governance that guarantee freedom of speech, transparency and accountability, political stability and effectiveness, rule of law, etc. have not been given much recognition. The paper concludes that the persistent institutional uncertainty, weak rule of law, political deceit, infrastructural decay, unemployment, monumental corrupt practices and insecurity need to be addressed for Nigeria to make progress, and that adequate effective measures are required from the political stakeholders to safeguard Nigeria's future and achieve development. Recommendations for better security system and development attainment are proffered.
\end{abstract}

Keywords: development, security, democracy, governance, Nigeria

\section{Introduction}

Right from the beginning of post-independence governance in Nigeria, the emphasis of Nigerian political leaders in governance has always been on development actualisation without ensuring that the necessary architectural foundations, such as national consciousness, integration, justice, equity, accountability, transparency, security, peace, etc. are put in place. The emergence of the military in governance coupled with ill-defined democratic system brewed unprecedented crises in the system. According to Ake (1996) and Abubakar (2004: 154), African leaders placed more value on capturing political power for themselves and grew increasingly fearful about what seems to be the grave consequence of losing to their rivals. Not only was coercion used to constrain the political expression of the masses, but discouragement and disillusion have been utilised to impose "political unity" in the midst of 

socio-cultural political pluralism. In the pursuit of power, post-independence leadership foisted personalised and authoritarian rule through their party system or military dictatorship. Their political competition has assumed the character of warfare, thereby paving the way for the ascendancy of specialists in violence and military dictatorship.

In view of this, it is noteworthy to state that the essence of every country's national interest is to provide for its citizenry, and make life more meaningful to them. In other words, the achievement of development requires leadership that is self-disciplined, visionary/missionary, courageous, etc. and the political will to lead the country into greatness. Despite its abundance natural resources both in mineral and human resources, Nigeria remains an underdeveloped country due to bad democratic governance and leadership roles. The activities of its political leaders are much more on how to be self-sufficient and selfsustained without considering the sustainability of the entire country as a whole. This has directly or indirectly built self-consciousness and centeredness, corrupt practices, ethnic marginalisation, hatred, disunity, insecurity, slow of development, etc. into the Nigeria system. In the 21 st century, Nigerians still think ethnically, and not nationally. They show capacity for self-increase and self-sustenance through dubious means than to care for the generality. That was why; Albert (2003: 23) states that:

The problems created by the leaders could be direct or indirect. The direct ones are where these leaders do fail to put the necessary infrastructure of peace in place, no jobs for the youths, no electricity light, et cetera. The absence of the entire infrastructure transforms the society into an assembly of frustrated men and women, who could be easily provoked into violent acts borne out of their frustration. This partly explains how most of the social conflicts started, and most of the youths that were used as cannon fodder in most of the violent conflicts in the countries are the frustrated young school leavers who feel let down by their leaders. While they (the unemployed youths) live in abject poverty, their leaders (many who came by their wealth through the dubious means) flaunt their affluence.

Albert's submission partly explains how the failure of political leaders in governance paves ways for insecurity in Nigeria. The Nigerians postindependence ill-defined political practices have led to destruction of lives and properties, ethnic affiliations, agitations and clashes, religious crises, mass unemployment, deprivation, corrupt practices, money laundering, infrastructural decays and pipeline vandalisation, militancy, bad governance, insecurity, etc. Nigeria has had four different Republics (1963 to 2011) without much meaningful achievement - in terms of security and development. The 
attributes and features of peace, security and development are lacking due to the insensitivity of Nigeria's political gladiators. The country transited from military rule to civilian rule in 1999 without a genuine constitutional framework on how the country would be governed. The citizens cast their ballots without knowing the kind of power that their elected representatives would exercise, or how various levels of government would interact and share power. It was all about political aspirants' veracity to deploy thugs, powerful associates, and perpetration of electoral violence or fraud to determine how the country would be governed. This has been so endemic that the electorates have found it difficult to vote for candidates on merit. The organised political and electoral violence, ethnic and religious militancy threatened the corporate existence of the country. All these are traceable to a widely held belief that past elections have neither been free nor fair.

Notwithstanding, Nigeria has had several economic development summits with none coming into fruition. The bane of the country's economic fortunes are bank fraud, bank collapse, 419ers, money laundering, infrastructural decays, unemployment, deprivation, corrupt practices, unaccountability, lack of transparency, child and women trafficking, illegal arms and weapons proliferation, oil bunkering, insecurity, slow rate of development, etc. The other economic sectors have been neglected for the petroleum sector. The available resources are either diverted for personal use or for political agitations. The lack of true democratic culture and absence of appropriate intuitive peace-building or preventive diplomacy mechanisms are among the problems that undermine Nigeria's growth and development. Nevertheless, the recent April 2011 general elections shows some signs of maturity and elements of commitment from the electorates provided the political office holders would not let down the electorate that put them to power. The emergence of Niger Delta crisis, ethnic clashes, Sharia law, Boko Haram and religious fundamentalism/fanaticism in Northern Nigeria are recent factors that constitute insecurity to the country in its match toward development. All these are parts of the defeated politicians' stratagem.

Likewise, daily struggle for survival has made it more difficult for Nigerians at the grassroots to organise or advocate for grassroots development. In Nigeria, the political office holders enjoy a rare luxury due to lack of reprisal for wrongdoings. Meanwhile, the true democratic system of governance guarantees a congenial environment where aspirations and lawful activities can be carried out freely without any intimidation. It ensures sustainable peace, stability and development that can improve service delivery, simplicity and accessibility procedural systems, fiscal responsibility and expenditure efficiency, higher levels of accountability and transparency, democratic principles, rule of law, stringent anti-corrupt measures, etc. In other words, the funda mental goal of a civilised society is to ensure law and order by maintaining and guaranteeing its citizenry general security and tranquillity. A civilised society ensures measures that secure citizens and their resources from the danger or risk of infiltration, sabotage, subversion, violence, theft, etc. The 
national insecurity situation in Nigeria is a pointer to the virtual failure of governance. This is because the primary purpose of every government is to guarantee the welfare and security of its citizens. All these threatened the likelihood of development architectural foundation in Nigeria. Therefore, the aim of this study is to investigate the influence of insecurity on Nigeria's development; the specific objectives are to examine, highlight and show how proper security management in Nigeria democratic dispensation can ensure sustainable peace and development. The study relied on secondary data derived from various sources.

\section{Conceptual Analysis of Development and Security in Democratic Dispensation}

Development as a concept defies a precise definition meaning. Duffield (1994: 38) defines it as a normative process of becoming a series of interconnecting movements leading from poverty and vulnerability to security and well-being. Seer (1995: 21-36) conceives development as the creation of conditions for realisation of human personality, which implies a reduction in poverty, unemployment and inequality. Anderson and Woodrow (1989: 12) see development as a process through which people's physical/material, social/organisational, motivational/attitudinal vulnerabilities are reduced, and their capacities for progress are increased. All these are general improvement in human conditions. They overcome problems like malnutrition, illiteracy, unemployment, diseases, slums, inequality, lack of technologies, insecurity, etc. Development process involves an enlargement of citizens' choices in terms of living a healthy and longer life, which includes political freedom that guarantees human rights and self respect. It is a central process through which human beings can transform themselves and acquire capacity to live a more rewarding and fulfilled life.

Development in human society is multi-facial in nature. To the individual, it is an increase in knowledge, skill, capability, creativity, self-discipline, responsibility, and material well-being. However, the achievement of these features of personal development is tied to the state or societal development. This is because the freedom, responsibility, skill, etc. can only have real meaning through some interplays within a society, which efforts complement one another in achieving success or progress. The respective society or state political structures are very important in actualising development because it is within these social rules that society members can interact, dialogue, trade, etc., and move forward. In other words, at certain level of social groups, development would imply an increase in capacity to regulate both the internal and external relationships (Rodney, 1972: 1-2).

Rodney (1972: 2) states that development in any society can be classified into two parameters, namely: political and socio-economical development. Political development is the advancement in governance, while socio-economic 
development includes advancements in economic and socio-cultural practices like technology, material well-being, per capital income generation, etc. The ability of a society to utilise opportunities that abound in its environment will determine its levels of development. The capacity or ability to deal with certain environment for development purpose is dependent on the extent to which society members can influence the law of nature for their benefits. To put development in its proper perspective, there has been a constant economic development within the human society since the origins of man. In modern day society, every country struggles to extend its controls over its environment, which can be deduced as development. On several occasions, human groups have displayed an increase in capacity to extract a living from their environment. Development is a universal need, and a condition that leads to economic expansion. The overall tendency of development is to increase production, and at a given time, increase the quantity/quality of goods in the society. This is associated with the change in quality or character of members of that society. In other words, the emphasis of an aspiring developing society should be on how to create a better living condition for its citizens that would create conducive atmosphere for growth and advancements. All these would create a condition for material and psychic welfare of people.

Nigeria is blessed and endowed with vast human and natural resources that can make it a developed nation. Ironically, despite these opportunities, it remains in the ranks of nations that are still underdeveloped. Many Nigerians live below the World Bank poverty level. Poverty continues to spread at alarming rates because of virtual stagnation of growth in per capita income and limited economic prospects. The widespread corruption in the country has worsened the situation. The extent of mass poverty in Nigeria remains unacceptable. It is noteworthy that in the midst of perennial mass poverty and demands for improved living conditions, respective governments have failed to give poverty alleviation a high priority.

On its part, security is defined as measure that ensures peace and development at large. It guarantees absence of fears, threats, anxieties, tensions, apprehensions of losing life, liberty, property, goals, values, etc. It is essential for every sustainable development plan. Security is a pre-condition for people's improvement, particularly, the poor. The concept of security goes beyond a fundamental military capability that aims at protecting a territory and its sovereignty. The emphasis of Nigeria political stakeholders has always been on traditional security and not on human security. Meanwhile, human security concept encompasses protection of lives and properties, a pre-condition for people's improvement, protection of human rights and provision for basic human needs, which is the best approach to human development. The need for peace in Nigeria's development aspiration cannot be over-emphasised. That was why peace is generally defined as absence of war, fear, threat, conflict, anxiety, suffering, violence, etc.; meaning, a state of peaceful coexistence. It involves activity that can lead to development. However, peace does not exist in the absolute absence of conflict, rather, it is relative. The concept of peace 
could be negative and positive. Peace is negative when it encompasses the application of force - the use of soldiers and police force. It is positive when the peace in place is legitimate; and positive peace leads to sustainable peace and security. The use of traditional security can only leads to negative peace, because it involves force application. Using conventional security mechanism at all times cannot lead to peace and security. That was why Attlee (19451951), the then Labour Party's Prime Minister of Britain, stated that:

We do not envisage an end to this victory. We are determined not only to win the war but to win peace. Plans must be prepared in advance. Action must be taken now if the end of the war is not to find us unprepared...

In other words, until the crushing burden of armament is lifted, Nigerians cannot enjoy the maximum social well being that is possible. They cannot build the city of their own desire under the constant menace of force application, aggression and insecurity. Freedom from fears and freedom from want must be sought together. This means that the connections between development and security have not been well understood in Nigerian's democratic dispensation. For instance, tensions among the political stakeholders in democratic governance and those that may help to bring about the peace, security and development in the long run need not to be overlooked.

Likewise, democracy has been universally defined as a means of peaceful leadership changes. It is a process of actualizing the true democratic system of governance that exposes electorates and aspirants to an experienced competitive power or leadership changes through electoral processes. But misconduct of democratic processes in Nigeria has been a major problem that undermined its true democratic culture and peace for decades. The true representative democratic governance is a system whereby the members of a society, community or organisation elect one or more persons to exercise their political interest on their behalf. The provision for democratic election in societies is intended for power to be exercised within the consent of the people. That was why democracy is defined as "government of the people, by the people and for the people". This means that all the political, economic and social forces need to interact freely without restrictions, limitations, or fear of harassment and intimidation by government security agencies. It is essentially government of consents, multiparty pluralism, electoral competition, agitation and rule of law. The reality on ground in most of the Africa countries is that the consent of the governed is taken rather than given. Their choice in the political system is limited to options produced by the few oligarchies. The celebration of democracy in Nigeria has had little or no chance for the poor person but the rich. The struggle for material things and political freedom compels Nigerians 
to partake in elections, but the material things and survival require freedom from political oppressions.

Democratic system in Nigeria has received much of its impetus from the political leaders and electoral commission failures, failures which have become a life time threat to security. The survival strategy that many Nigerians spontaneously devised to cope with the economic adversity and to reduce their vulnerability is the electoral means. But their political liberty and equality should not be subverted by cheating, fraud, vote buying, intimidation or fear. This implies that every interested aspirant or individual should be able to participate appropriately without any hindrance or frustration. The principle of democracy includes widespread participation, consent of the governed and public accountability of those in power (Ake, 1994: 34). Democracy acknowledges the right of all citizens to dissent. It is characterised by social integration. It makes possible a widespread habit of tolerance and accommodation of differences over issues and policies. It could be said that democracy is superior to other forms of governance because it secures the rights and interests of every person from being disregarded. It provides good atmosphere for one to stand on his/her rights. These attributes make it more preferable to a political dictatorship. It determines the country's national success or failure. If a nation is not careful, her national character may compel unconscious dictatorship under the aegis of democracy. The national character is a product of orientation, culture and interaction. The problem of lack of trust and fear has been hindering the success of democratic governance in Africa. Political trust is the belief that the government is operating according to one's normative expectations (Miller, 1974: 989). This could be inferred to mean the legitimacy which has to do with the belief that government institutions and authorities are morally and legally valid, and widely accepted.

Broadly speaking, the three types of democracy that can be identified as a widely prevalent are plurality, consociation/proportional representation and simple majority. Transplantation of an ideal democracy in Nigeria has led to institutional problems like corruption, ethnic cleavage/marginalisation/crisis, insecurity, political and electoral violence, etc. Employment of unlawful forces by the parties' supporters or members is prevalent in order to intimidate opponents and create unnecessary threats to a democratic process. Democratic election in Nigeria is poisonous. It is politics of war-acrimony, hatred for peace and mudslinging not for love or brotherhood; anarchy and discord, and not for orderliness and concord. It is the politics of cleavages, divisions and disunity, and not for co-operation, consensus and unity; it is the politics of hypocrisy and charlatanism, not for integrity and patriotism. It is the politics of rascality, and not for maturity; of blackmail and nearly gangsterism, and not for constructive honest contribution (Omoruyi; 1994: 124).

In the same vein, there is an unbridled flagrancy in the smuggling and use of arms and ammunition by the political support class. The result has been that political opponents are either intimidated or outrightly killed. The power of incumbency also creates tension in politics. Elections are rigged in a 
traumatising manner that offends the psyche of the citizens. Even if election is seen as the only ritual that citizens have to perform, such formal ritual is now endangered or even outrightly distorted by violence. Often, many people are not allowed to vote or be voted for, many more people especially in the rural areas do not even see either the colour of the ballot box or balloting paper. Many are often disenfranchised. Political corruption is pervasive as it affects all state stakeholders and actors. The menace is linked with grinding poverty, rising unemployment and value-vacuum not just within the political class but desperately angling for power. The sanitisation of political process is a task that must be done although it is proving quite intractable. For development to manifest in Nigeria democratic governance, emphasis of the leaders needs to be on human security and not on traditional security. Nigeria leaders need to transcend from ill-define democratic system to an acceptable global process of democracy.

\section{Theoretical Analysis of Development and Security Situation in Nigeria's Democratic Dispensation}

The first explanation of Nigeria's insecurity and underdevelopment in the democratic dispensation is through the human needs theory. The theory, like frustration-aggression and deprivation theories, states that all human beings have basic needs which they seek to fulfil. The denial or frustration of these needs by other groups or individuals would affect them immediately or later, and lead to or generate conflicts (Rosati et al., 1990). The basic human needs include physical, psychological, social, and spiritual needs; providing access to one and denying or hindering access to another will amount to denials and could make people resort to violence in an attempt to secure the needs. Human needs theory identifies the needs deprivation as a source of conflict and insecurity. Likewise, Burton (1990: 72) demonstrated the frustration of human needs as a force that produces aggressions when individuals strive to satisfy their basic needs. Burton asserts that individuals could not be taught to accept practices that would destroy their identity and goals that are attached to their needs; but they can be forced to react against the factors, groups and institutions that threatened their needs. Nevertheless, human needs for survival, protection, affection, understanding, participation, creativity, identity, etc., are shared by people, and are irrepressible. They have components like recognition, identity, security and autonomy, and bonded with those that are unable to give up easily no matter how a political or social system tries to frustrate or suppress them.

Gurr (1970: 22) and Mar-Neef (1991), on relative deprivation thesis, state that the tensions between deprivation and potential can be addressed by human needs theory, but when they are not sufficiently satisfied, the economic and political crises will continue to grow. The political and economic imbalances within the society would lead to the fear of survival, xenophobia, crime, 
violence, refugees, human displacement, political marginalisation, insecurity, etc. In other words, the frustration of human needs would hamper the actualisation of groups or individuals' potentials, and subsequently lead to conflict and insecurity. All these are factors assumed to insecurity into Nigeria's democratic governance, which must be addressed for development attainments. Nigeria democratic system has failed on human security; instead, the traditional or conventional security system that involves force applications has been its major emphasis, which is not the best for Nigeria's development aspirations.

On democratic practices, Nigeria's political situation has taken different dimensions right from the beginning in both theory and practice. The following are the global democratic types - direct, indirect, constitutional, participatory, consensus, consociation, representative, liberal, etc.; and they are not exclusive of one another, although, they can be independent of one another or co-exist in a single system. Meanwhile, the direct democratic schools advocate a political system where citizens could participate in decision-making personally, contrary to relying on intermediaries or representatives. They argue that democracy is more than a merely procedural issue. It gives the voting population power to change their constitutional laws, and putting forth their good initiatives. The constitutional democratic schools believe in governing through constitution, while the participatory democratic schools posit consent or consensus decision-making that offers greater political representation. The participatory democratic schools allow decision-making to be in proportions, that is, decision-making should be based on how people or areas are affected. Such system hardly gives room for any majority/minority cheating or tyranny.

Consensus democratic schools proffer the application of consensus decision-making to the legislative processes. This is characterised by a decision-making structure that involves and takes into account broader range of opinions, and the feature participatory increase that determines political agenda. It prevents any linguistic or cultural group domineering in decisionmaking. The consociation democratic schools view democracy from a system that guarantees group representation; that is, a group decision-making process that does not only seek for participants' agreement, but also manage or mitigate the minority objections. Its attributes are inclusive, participatory, cooperative, egalitarian, solution-oriented and most logical, etc. Consociation decisionmaking process has several roles which are designed to make a process run more effectively. In consociation democracy, the centrifugal tendencies inherent in a plural society are counteracted by cooperative attitudes and behaviours of leaders that are from different segments of the population (Lijphart, 1977: 1). It has grand coalition of political leaders or parties; such as cabinet grand coalition in parliamentary system or grand council, mutual veto or concurrent majority rule, power sharing, proportionality and autonomy.

Representative democratic schools believe in the true representation that suggests the election of government officials by the people. It is a system of simple majority or a plurality of votes. Some representative democracies 
incorporate elements of direct democracy, such as referendums. The main characteristic of the representative democracy is that the representatives are elected by the people to act in their interest. It is where the sovereignty of the people is held by their representatives. To liberal democratic schools, democracy is a system where those who hold power are elected in competitive elections with a secret ballot and wide franchise, that is, a situation where there is freedom of speech, religion, organisation, and a constitutional framework of law to which the government is subordinated and guarantees equal rights. The liberal democratic system gives room for negotiation and compromising. It is a representative democracy that emphasises individual liberties, consent of the governed and the governing. The representatives are elected in multi-party elections that are considered free and fair. The power of representatives in a liberal democracy could only be curtailed by the constitution or other measures like independent judiciary, bicameral legislature, separation of powers, etc., so as to balance representative power. Therefore, it is injustice to withhold from anyone the privileges of having his voice reckoned with in the disposal of the state or country's affairs, in which he/she has the same interest as other people do, unless for the prevention of greater evils.

Political equality is a basic principle of democracy, and any form of restricted franchise infringes the principle of equality between individual to some degree. Once a person's right to vote is denied, his/her interest may be overlooked by the legislature and the executive. Democracy deters arbitrary arrest of citizens, but entrenches protection of civil liberties, such as freedom of thought and expression, freedom of religion, freedom of assembly and association, etc., and entrench development. Mill (1920) notes that rulers and ruling classes are under necessity to consider the interests and wishes of those who have the suffrage. The universal adult suffrage tends to invert the true and natural relationship between wisdom and folly. The suffrage should be based on citizenship and age; so that everybody will be allowed to elect representatives of their choice. Adult suffrage is assumed to be the most ideal system, because it is based on electorate's constitution. The community members need to be well educated on electoral process so that multitudes will not ignorantly cast their votes as it is directed by other individuals or organisations. The universal adult suffrage orientation should be given before the elections time. The administrative difficulty of managing a vast electorate, and ensuring of adequate supply of reliable and impartial returning officers, polling officers and security personnel, is in fact the major challenge to Nigeria's democracy.

Since representative government is the only practicable method of establishing democracy in the present dispensation, periodic elections become necessary for this purpose. Each citizen of a country should have the right to vote or be voted for, in accordance with the prescribed age. Nobody should be disqualified on the grounds of caste, creed, sex, language, region, etc; but many 
Nigerians are indirectly disqualified through electoral malpractice by the political leaders. Under the adult suffrage, the voting should be secret so that each citizen can exercise his/her right without fear or favour. Universal adult suffrage is regarded as a necessary condition in democracy. Periodic elections require that the citizen's representatives should be chosen for a limited period so that the party that comes to power is able to implement its policy and programmes. It is obliged to renew the confidence of the people, if the need be to continue in power. Also, the oppositions should have the opportunity to bring the shortcomings of the ruling party to the notice of the people, as an alternative policy and programme, with a view to wining the next election. Political offices should not be confined to any class or groups.

Given the requisite analysis, the ultimate goal of Nigeria's nascent democratic governance should be to transformed the society and achieve the needed sustainable peace and development, that is, a transformation from the state of political and electoral violence to one characterised by peaceful coexistence and proper security. The psychological and security relationships require a better understanding, and should be well addressed if the aim and objectives of democratic governance will be brought into fruition. The conditions for proper security and development entrenchment in Nigeria require strategies like good democratisation, protection of human rights and implementation of rule of law. The belief in human rights sometimes makes the people in democratic systems feel reluctant to go to war or constitute insecurity. It could also change peoples' perceptions of waging war.

Bruce (1993: 5-11) believes that democratic culture could affect the way in which the leaders manage their conflicts. Liberal leaders face institutionalised constraints that impede their capacity to mobilise state's resources for violence without the consent of the broad spectrum of interests. The credibility of liberal states allows them to negotiate for sustainable peace. The participation of the public in open debates sends clear and reliable signals regarding the intentions of the state. There may be mistrust and unwillingness to make concessions in a non-democratic society. In other words, electoral process in Nigeria needs to entrench a true democratic system like representative/liberal democracy if its aims on security management and development attainments will be achieved. The "beauty" of democracy is accommodation of opposing views, separation of powers, opinions, criticism, free press, flexibility, unhindered trade union activities, human rights' activities, peaceful change of political leaders after elections, conceding defeat after elections, freedom of association and assembly, etc. In the Nigerian democratic dispensation, political leaders need to work for unifying factors that will prevent insecurity at large and entrench sustainable development. All hands should be on deck to work for Nigeria's development in its democratic dispensation. Development and proper security management attainment is a joint project that all Nigerians must ensure and achieve in its post-military era. 


\section{Development and Security Situation in the Democratic Dispensation of Nigeria}

The issue of underdevelopment and insecurity has been a serious concern to all Nigerians. This is due to lack of good governance that can guarantees absence of fears, threats, anxieties, tensions, apprehensions of losing life, liberty, property, goals, values, free and fair elections, respects for proper constitutional process that eliminate lawlessness, etc. Meanwhile, elections constitute a fundamental aspect of every democratic process, indeed it is the key hallmarks of modern democracy. Elections in Nigeria continue to suffered unimaginable malpractices; Nigeria political stakeholders have failed to embrace transparency in the electoral processes. For Nigeria to become a credible member of global democratic community, its leaders need to meet up with the minimum parameters for free and fair election in the democratic process - such as open competitiveness, independent judicial system and rule of law. Its citizens need a proper electoral orientation and information that is free and open to everybody. This is because the recent political power struggle in Nigeria has been so intense and absorbing that it has overshadowed everything governments do including the pursuit of development. According to Diamond (2004: 224):

Countries that have failed to realise their development potential in the past half-century have invariably suffered yawing deficits of good governance. In these development laggards, bad governance constitutes a treacherous obstacle...

The most intractable obstacle to vigorous development is poor governance. As a matter of fact, it must be emphasised that bad governance is a pervasive and profound obstacle to development; just as good governance promotes the accumulation of financial, physical, social, and political capital, bad governance inhibits or drains away the accumulation. In view of this, a good socio-political and economic system that eliminates poverty and insecurity are key objectives to development attainments. Development in general encompasses freedom from fear and arbitrary arrest, freedom of speech, freedom of association, and the right to run for and hold political office (Sen, 1989 and Afeikhena, 2004: 207), which also involves economic, social, environmental and cultural dimensions. Development is seen as a transformation of human society, and a move from the old ways of thinking or old forms of social and economic organisation to the new ones (Stiglitz, 2000). According to Stiglitz, the new view of development and developmental transformation involves a change in the way people think and the way society functions - a change in norms, expectations and institution. The lesson from the 20th century was that successful development ultimately derives from a home-grown strategy, and not from imported theories. Most of the 


\section{The Nigerian Journal of Sociology and Anthropology}

industrialised countries owe their success on development to their workable models. Nigeria democratic dispensation has failed to fashion out its own brands of development.

The state of insecurity in Nigeria has prevented some investors from delving into development activities. Most of the essential infrastructures of development are either in a state of decay or not available. The emphasis or activity of political leaders in Nigeria is on how to collect outrageous allowances. The issues of corruption, lack of transparency and accountability have drained virtually all the resources that are meant for development, and directly or indirectly constitute insecurity to the country due to human needs deprivation, total neglect, massive unemployment, etc. Writing on the theory of political community, Omafume (1995: 46) states that if all men were virtuous and rational, there would be no need for laws and states. A completely virtuous person is governed by reason, not by external laws. The state originated because of imperfections of human nature. In other words, every state need to be organised in such a way that promotes the ascendancy of reason, just as rationality of virtuous man and the essential rationality of universe. To achieve the ideal political community, political leadership needs to be left to virtuous persons who have philosophical insight, those who live by reason. The ideal political community is the one in which the guardian class, the military and industrial class perform their functions without mutual interference.

There is no doubt that development and security have a mutual relationship that makes them inseparable. The Nigerian socio-economic system and political history are replete with cases of bad governance and insecurity that led to stagnation. The links between elements of good governance such as public opinion, transparency and accountability, political stability, government effectiveness, regulatory burden, rule of law, graft and development are quiet obvious. The problem of development in Nigeria lies within the incompatibilities of the quest for self interest/survival, maintenance of existing forms of domination, which has led to misuse of manpower resources, ethnic sentiment and marginalisation, inefficiency and corrupt practices. The abnormality in Nigeria's political appointments promotes mediocrity and hinders attainment of development goals. Some positions that require specialist knowledge and skills are given to some people based on their political involvements or place of origin. The damage done to Nigeria's development has partly been the problem of incompetence or corrupt practices, which are not just physical but also mentally. The struggle to obtain and keep power has transformed Nigeria to all forms of ethnic warfare where all forms of forces are being mobilised. The winner in the political race assumes absolute powers, and the loser faces a real prospect of losing liberty and even life (Gowon, 2009: 1011). All these have transformed Nigeria into a "den" of political armed conflicts and insecurity that has been so appealing, and hindering the pursuit of development.

On the rotten governance, Diamond (2004: 225) asserts that individuals seek government positions in order to collect rents and accumulate personal 
wealth by converting public resources into private goods. There is no commitment to public goods and no confidence in the future; communities as well seek immediate government jobs or favours in a zero-sum struggle over a stagnant and potential fleeting stock of resources. There is no respect for law and order. The judicial system is politicised and routinely suborned, or so demoralised and starved of resources to the extent that it cannot prosecute corrupt conduct in the public and private life. Government decisions and transactions are deliberately opaque in order to hide their corrupt nature and evade embarrassing disclosures. Information about how government works and how contracts are awarded is simply unavailable. Exposure of corrupt deals typically brings little more than embarrassment because the rule of law does not function to constrain or punish the wrong behaviour of the public officials. Power is heavily centralised, and institutions of scrutiny and accountability function only on paper, or episodically, to punish the more marginal miscreants or the rivals of the "powerful". Nigeria lacks a sense of public purpose, discipline, and esprit de corps; the civil service, police, customs and other public institutions function poorly and corruptly. Nigeria corrupt practices are rife from the top to the bottom of governance because it has been the prevailing climate set by the leaders over a long time; bad governance and its attendant social and cultural ills breed rising social frustration, political violence, development failure, and ultimately state collapse.

According to the United Nations Security Council (1998: 5), the nature of political power in many African states, together with the real and perceived consequences of capturing and maintaining power, is a key source of conflict across the continent. Where there is insufficient accountability of leaders, lack of transparency in regimes, non-adherence to the rule of law, absence of peaceful means as to change or replace leadership, or lack of respect for human rights, political control becomes excessively important, and the stakes become dangerously high. Gleditsch (2001: 216) states that armed conflicts pose a major challenge to development in Africa. This is destructive to any environment. Therefore, for peace and stability to endure in Africa, there is a need to complement the process that involves the quest for peace and development. The development attainment in most cases helps to address the root cause of conflict and insecurity. The crisis of insecurity in the democratic dispensation has forced various segments of the country to live in a precarious condition. The political elites are so much interested in pursuing the fastest route of personal wealth than the collective progress and development. They use shorter-term measures to generate foreign exchange rapidly to purchase luxury goods from industrialised countries. They are not relying principally on their country's production efforts, given the relative long periods it would take to obtain profits. They grow largely wealthy through illegal appropriation of state's resources, and use of state's power for personal gains. 
Development is a long-term process but Nigeria elites prefer growth through shorter-term measures. The political elites are assuming and sustaining power through their ill-defined democratic processes that worsened standards of living over the years. They apply mixtures of soft and hard measures to address persistent demands for improvements. Their soft measure is dishonest rhetorics, designed and pronounced corrupt practices. Their hard measure is violent repression based on huge military and para-military security capability. The scourge of insecurity constitutes a major impediment to the efforts of eradicating poverty and ensure of sustainable development. The proliferation of conventional weapons, most especially the small arms and light weapons, posed a significant threat to the stability and security of the country. The use of weapons sustained conflicts, exacerbates violence, fuels crime, terrorism, poaching and human trafficking. The excessive use of weapons has destabilised the country's accumulated resources, undermined its governance and inhibited development.

Most times, the absence of political will and appropriate logistics often frustrate the attempts of activating mechanisms that deal with actual or potential conflicts. Equally threatening the development of Nigeria is the persistence of poverty, which has created the issue of insecurity with respect to a decent livelihood and human survival. It reduces the ability of people to live productive lives, and exacerbates identity conflicts along the communal, ethnic, religious and regional lines. The sincerity of national identity has become another problem to the Nigerian system. For example, Nigeria is still incapable of dealing effectively with the issues of identity and citizenship. The issue of states of origin versus out-of-state origin undermines the process of national integration and unity; the issue of federal character in virtually all federal government appointments and programmes had undermined competence. The social identities have been historically constructed to define certain sets of people as the most significant people; this needs to be changed through a socio-political transformation. The issue of identities most often arose when there is a need for resources struggle. The recruitment of young men and women to armed bands is undoubtedly a function of large number of young school leavers and unemployed youths doing nothing and with no hope for the future. The high incidence of inter-communal violence is due to the growing competition for resources and persistence of poverty.

Insecurity and poverty are intertwined, and their persistence can frustrate Nigerians' integration and development processes. Ake (1985), on "Why Africa is not developing", states that the answer to this melancholic question is in two folds. On one hand, the slow rate of development has to do with African's internal arrangements, where the state itself is likely to function as an obstacle to the development than as an agency of economic and social transformation. This may be due to the fact that, rather than being a set of impartial institutions serving the generality interest, the state and the resources under its control are for the rulers and their entourage. On the other hand, the slow pace of development is a function of western development strategies 
whose main objective is to further integrate African rulers into international networks of wealth and privilege rather than to promote development and democracy in general.

The fundamental goal of any civilised society is to ensure law and order by maintaining and guaranteeing the citizens' general security, and to ensure public tranquillity. National security entails measures and facilities that secure citizens, properties, resources, etc., from the danger or risk of infiltration, sabotage, subversion, violence, theft, etc. The national insecurity situation in Nigeria is a pointer to the near failure of governance. This is because the primary purpose of every government is welfare and security of its people. This has been found wanting in Nigeria. Acts of insecurity such as crimes, kidnappings, violence, robberies, etc. are prevalent. Meanwhile, security is defined as a measure that ensures peaceful co-existence and development at large, and guarantees absence of fears, threats, anxieties, tensions and the apprehensions of losing life, liberty, property, goals, values, etc. Security is very essential to any sustainable development. It is a pre-condition for people's improvement and development, particularly, the poor.

According to Akindele (2003: 274), "there is now a general awareness that good governance is absolutely indispensable to promotion, achievement and maintenance of peace and security within and among the nation-states. Closely linked with good governance is development, which is the arrowhead of human security. Both good governance and development mutually reinforce and support each other in laying the foundation for a durable edifice of peace and security. A Somali elder once states that "development is about human beings. They need five things; the first is water. It is the first thing needed to live. Without it, a plant, animal or baby dies. The second is food. Without enough of it, life will be miserable and short. Health is another need; otherwise people will be sick and unproductive. Fourth is education. Man needs to learn how to open new horizons and unlock new possibilities. There is a fifth need - peace, order, and security. Without it, none of the four basic needs can be sustained" (Adedoyin, 2011: 36-37).

Nigeria's fledging civilian regime has been disfigured by excessive economic abuse, including the embezzlement of public funds, huge payments for fictitious or abandoned contracts, inflation of contract figures, overinvoicing, double debiting and unauthorized public expenditures. The context of corrupt and failed governance has been propitious for the expansion or proliferation of thuggery groups of unemployed or underemployed youths, including the so-called ethnic militias or vigilantes, who were available for fraudulent manipulation and violent mobilisation during the elections. The impact of bad governance on national unity has spawned bad relationship, distrust, corruption, nepotism, and ethnocentrism, while other effects are economic problems, poverty and ethno-regional, religious struggle and unhealthy competition. The distorted distribution of the nation's wealth has 
resulted into enrichment of minority at the expense of an impoverished majority. The persistent institutional uncertainty, weak rule of law, deceit, infrastructural decay, weak institutions of state and monumental corruption are problems of security and development. All these and more have been the major problems that undermined Nigeria's security and development. Therefore, adequate effective measures are required from the stakeholders in governance in order to safeguard the future of Nigeria and achieve its development aspirations.

\section{Recommendation}

The following steps are suggested for proper security management and development in Nigeria's democratic dispensation, which no doubt will help to reduce the level poverty and mass suffering in the country. Facilitating proper development process requires true government of the people by the people and for the people. People who have never been directly or indirectly implicated in questionable deals, or people of transparent character, are needed in governance; in other words, the body responsible for governance should involve people of higher integrity and reputation, those who are accountable to the people and not to themselves. This will prevent political offices from being ransacked and mortgaged by dubious politicians. Nigerians should not entrust the destiny of their country in the hands of dubious politicians who can crush the national interest under the jackboot of criminality and selfishness. A good democratic system of governance is regarded as mandatory, and a prerequisite for sustainable growth and development. The emphasis of stakeholders in governance should be on human security and not on traditional or conventional security. The following specific recommendations are proffered:

1. Nigerians in the 21st century need to eradicate the use of state origin but emphasize their national unity, consciousness and integration. They need to join hands together to foster good democratic process and governance.

2. Political office holders need to provide for basic infrastructural facilities and human security. They should realise that governance is all about service to humanity and not opportunity to enrich themselves. They should know that provision for human security that can ensure protection of human rights, basic infrastructural needs, etc. will lead to development.

3. The lack of job opportunities for the unemployed citizens has constituted unnecessary threats to Nigeria system. Government and private individuals need to engage in activities that can provide jobs for the citizens. The country's resources need to be fully deployed for development activities in general.

4. There should be rule of law and stringent anti-corrupt practices crusade. In Nigeria's democratic dispensation, the rule of law that encourages checks and balances among the three arms of government - legislature, 
executive and judiciary should prevail. The anti-corruption crusade in Nigeria needs to be strengthened through the law, in order to prevent socio-political and economic sabotage.

5. There should be a constitutional provision against the money-bag politics in Nigeria, where anyone found guilty of this offence will be prosecuted according to the law. The provision will prevents further acrimony in politics.

6. There is need for regular refresher courses for all security personnel in Nigeria, where both officers and recruits can be re-trained and reequipped with modern-day security techniques, facilities and information.

7. The Nigerian social system requires a good civic education on security knowledge, skills and development orientation.

8. Nigeria citizens require both long and short term development plan and implementation from their political stakeholders, and which must be handled by those who with integrity and have the interest of the society at heart.

\section{Conclusion}

From the foregoing discussion, it is evident that Nigeria's democratic dispensation in its post-military era has failed to raise the hope of average citizens, but has rather dampened it. The activities of Nigerian political players leave much to be desired. Politically induced insecurity has been at the centre stage of politicking to the extent that political gangsterism has infected the wider society, and even threatening the likelihood of development attainment in the country. In these circumstances, there is need for national re-orientation of both the political class and the governed, to eschew politics of bitterness, parochialism and selfish accumulation. Citizens - the political and generality of Nigerians - need to conceive democratic governance as service to humanity rather than opportunities for those in power to enrich themselves. Politicians should think of how to use the mandate of people for national development rather than selfish empire building. It is through this orientation that security and development will thrive in Nigeria, leading to creation of the enabling environment for self actualisation.

\section{References}

Abubakar, D. 2004. Leadership and the Challenges of Rebuilding A Nation, in: Adigun, A.B; Diamond, L and Onwudiwe, E. 2004 (eds.). Nigeria's 
Struggle for Democracy and Good Governance. A Festschrift for Oyeleye Oyediran, Ibadan: University Press.

Abubakar, M. 2005. The National Questions and Democratic Consolidation in Nigeria; Lecture delivered at 3rd Annual Hon. Babatunde Oduyoye Lecture, Ibadan: Jorgor Centre.

Adebanwi, W. 2004. Democracy and Violence: The Challenges of Communal Clashes. In: Adigun, A.B. Diamond, L.\& Onwudiwe, E. (eds.). Nigeria's Struggle for Democracy and Good Governance. A festschrift for Oyeleye Oyediran. Ibadan: University Press.

Adebayo, A. 1997. Popular Participation, Democracy and Development: Is there a Dialectical Linkage, in: Adebayo, A. et al. (eds.). 1997. Nigeria: Renewal from the Roots? London and New York: Zed Books in Association with African Centre for Development and Strategic Studies (ACDESS) Nigeria, Ijebu-Ode.

Adedoyin, A. 2012. Global Unrests, Regime Changes, Terrorism and Developed Nations' Agenda. In the fifth Annual Society for Peace Studies and Practice Conference, University of Ibadan, Ibadan, Nigeria.

Adedoyin, A. 2011. Peacebuilding and Democratic System in the Africa Postconflict Era. A World Conference on Universal Culture for Democratic Sustainability and Peace Development. National University Commission, Abuja, Nigeria.

Adedoyin, A 2011. Elections and Nigeria's National Security: A Paper Presented in a National Conference on Democratic Elections and Nigeria's National Security, Peace and Conflict Studies Programme, Institute of African Studies, University of Ibadan, Ibadan, Nigeria.

Adedoyin, A. 2010. Governance and Peacebuilding in Post-Conflict Liberia (2006-2010). A Ph.D. Research Proposal in Peace and Conflict Studies Programme, Institute of African studies, University of Ibadan, Nigeria.

Adedoyin, A. 2008. Urban Violence and Security. A Course Guide and Course Material written for the National Open University of Nigeria, Lagos.

Adedoyin, A. 2006. Corruption and Violent Conflict in Nigeria. MA Dissertation, Submitted to the Institute of African Studies, University of Ibadan.

Adigun, A.B.; Diamond, L. \& Onwudiwe, E. 2004. (eds.). Nigeria's Struggle for Democracy and Good Governance. A Festschrift for Oyeleye Oyediran. Ibadan: University Press

Afeikhena, J. 2004. Governance and the Development Crisis. In: Adigun, A.B. Diamond, L. and Onwudiwe, E. (2004). Nigeria's Struggle for Democracy and Good Governance. A festschrift for Oyeleye, Ibadan: University Press.

Ake, C. 1996. Governmental Instability. Nigerian Forum, January-March, NIIA Publications, Lagos, Nigeria.

Ake, C. 1994. How Politics Under-develops Africa. In: Adebayo, A. et al. (1991), The Challenge of African Economic Recovery and Development, London: Frank Cass. 
Ake, C. 1992. The Feasibility of Democracy in Africa: A keynote address at the Symposium on Democratic Transition in Africa, Organised by Centre for Research, Documentation and University Exchange, Ibadan, University of Ibadan.

Ake, C. 1985. Why Africa is not Developing, West Africa, June 17.

Akindele, R.A. 2003. Civil Society Good Governance and the Challenge of Regional Security in West Africa; African Strategic and Peace Research Group (AFSTRAG); Ibadan: Vantage Publishers.

Albert, I.O. 2003. Mainstreaming Positive Leadership in Conflict Transformation, Nigeria. Lagos: Centre for Social Science Research and Development.

Albert, I.O. 2001. Building Peace, Advancing Democracy: Experience with Third-Party Interventions in Nigeria's Conflicts; Ibadan: John Archers (Publishers) Limited.

Anderson, M. \& Woodrow, P. 1989. Rising from the Ashes: Development Strategies in Times of Disaster, Boulder CO: West-View Press.

Appadorai, A. 2004. The Substance of Politics. New Delhi, India: Oxford University Press.

Attlee, C.R. 1946. A Speech at the International Labour Organisation Conference in 1941. In Vijaya, K. (2006). The World Greatest Speeches; A Collection of Some of the Most Famous and Motivational Speeches from around the World, India, Sterling Publishers (P) Limited.

Ayandiji, D.A. 2004. Party and Electoral Politics. In: Adigun, A.B. et al. (2004) Nigeria's Struggle for Democracy and Good Governance. A Festschrift for Oyeleye Oyediran. Ibadan: University Press.

Bruce, A. 1993. An Integrated Framework for Peacebuilding, Human Rights and Development, London: University Press.

Burton, J. 1990. Conflict; Human Needs Theory. London: Macmillan.

Diamond, L. 2004. Building A System of Comprehensive Accountability to Control Corruption, in: Adigun, A.B.; Diamond, L. and Onwudike, E. (2004). Nigeria's Struggle for Democracy and Good Governance. A Festschrift for Oyeleye Oyediran, Ibadan; Ibadan University Press.

Diamond, L. 1985. Nigeria, Pluralism, Statism, and the Struggle for Democracy. In: Diamond et al. (eds), Democracy in Developing Countries, Lynne Rieuner Publishers Boulders, Ibadan University Press.

Duffield, M. 1994. Complex Emergencies and the Crisis of Developmentalism. In: Maxwell and Buchanan-Smith, M. (eds.) Linking Relief and Development. Brighton: Institute of Development Studies. Vol. 25, No. 4.

Gauba, O.P. 2007. An Introduction to Political Theory. (Fourth Edition), Macmillan India Limited, 27/487.ZB Dilshad Garden, Delhi. 
Gleditsch, N.P. et al. 2001. Armed Conflict 1946-1999: A New Era Data Set. in Chester Crocker (ed.). Turbulent Peace; The Challenge of Managing International Conflicts, Washington, DC: Institute of Peace Press.

Gowon, Y. 2009. Leadership and the Challenges to Africa's Development in the $2 I^{\text {st }}$ Century. National War College, Abuja, Nigeria Graduation Lecture Series No 14, August 4.

Gurr, T.R. 1970. Why Men Rebel. Princeton: University Press.

Gurr, T.R. \& Harff, B. 1994. Ethnic Conflict in World Politics, Boulder, Colorado: Western View Press.

Lame, I. \& Odekunle, F. 2001. Fighting Corruption and Organized Crime in Nigeria: Challenges for the Millennium, Ibadan: Spectrum Books Limited.

Laski, H.J. 2008. Grammar of Politics; (Fourth Edition), Surjeet Publication, 7-K, Kolhapur Road, Kamla Nagar, Delhi-110007, India.

Lewis, P. 1993. End Game in Nigeria; The Politics of a Failed Democratic Transition. African Affairs.

Lewis, P. 1999. Politics and the Economy: A Downward Spiral. In: P. Beckett and C. Young, (eds.), Dilemmas of Democracy in Nigeria.

Lijphart, A. 1977. Democracy in Plural Societies: A Comparative Exploration, New Haven and London: Yale University Press.

Mar-Neef. 1991. Modern Social Theory on Conflict, New York: Free Press.

Mbeki, T. 2003. The African Renaissance: Challenges of Development and Security in the New Millennium. National War College, Abuja, Nigeria Graduation Lecture Series, No 5, December.

Mill, J.S. 1920. Considerations on Representative Government, New York: Liberal Arts Press.

Miller, R. 1974. The Ecology of Governance, Parliamentary Centre.

Nwabueze, B.O. 1989. Our March to Constitutional Democracy, the 1989 Guardian Lecture, Lagos, Nigeria. Delivered on July 24.

Nwabueze, B.O. 1994. Nigeria '93: The Political Crisis and Solutions, Ibadan: Spectrum Books Limited.

Nzongola-Ntalaja, G. 2001. Regional Integration and Africa's Development in the $21^{s t}$ Century: Issues and Strategies. National War College, Abuja, Nigeria Graduation Lecture Series No 6, July 24.

Odekunle, F. 1986. Nigeria: Corruption in Development, the 1982 Proceedings of the Nigeria Anthropological and Sociological Association, Held in Zaria, May 10-13.

Olawale, E. 2006. Checkmating Corruption in Electoral Politics, the Nigeria Tribune, Ibadan: tribunepolitical@yahoo.com

Omafume, H. 1995. Governance and Democratic System in Africa, World Bank Project.

Omoruyi, O. et al. 1994. Democratisation in Africa: Nigeria Perspectives, vol. 1, 2\&3. Benin City: Hima and Hima Limited.

Rodney, W. 1972. How Europe Underdeveloped Africa, Abuja: Panaf Publishing, Inc. POWA Complex A.Y.A Asokoro. 
Rosati, J. et al. 1990. A Critical Assessment of the Power of Human Needs in World Society. In: Burton, J. and Dukes, F. (1990), Conflict: Human Needs Theory, op cit.

Seer, D. 1995. Introduction: A Review of Development Studies. In: Ayres, R. (ed), (1995). Development Studies: An Introduction to Selected Reading, Dartford: Greenwich University Press.

Sen, A. 1989. Development and Freedom. New York: Anchor Books.

Stiglitz, J.E. 2000. Development Thinking at the Next Millennium. In Pleskovic \& Stern (eds.). Annual World Bank Conference on Development Economic. Washington, D.C; the World Bank.

Suberu, R. 1996. Ethnic Minority Conflicts and Governance in Nigeria. Ibadan: Spectrum Books Limited.

Tony, O. \& Desmond, U. 2004. The Federal Government is Very Corrupt, The News Magazine, Lagos Nigeria.

Wade, M.A. 2004. Francophone/Anglophone West Africa's Approaches to Sub-regional Security and development in the Next Decade. National War College, Abuja, Nigeria Graduation Lecture Series No 7, September.

UN 1998. United Nations Security Council Resolution 1171, June 5, 1998. 